\title{
MOTIF HIAS PADA PELIPIT CANDI
}

\section{CORNICE AND PLINTH DECORATIVE MOTIFS ON TEMPLE}

\author{
T.M. Rita Istari \\ Balai Arkeologi Yogyakarta \\ ritaistari@yahoo.com
}

\begin{abstract}
Decorative motifs found in Hindu and Buddhist temples, usually are depicted on almost all parts of buildings. Decorative motif in the form of reliefs consisted of geometric ornaments, nature, plants, animals, and humans. Relief there is a series of panels connected to one another with stories taken shadow-play epic. Fables are also often depicted. Stories with animals as the main character containing morale for human's life. Temple has 3 main parts, namely the base, body, and roof of the temple. In addition there is also a section called cornice and plinth. This serves as a separator between the three parts of the temple. To add beauty and give the impression of a slender building, then on cornice and plinth was carved decorative motif that surrounds the temple. The various decorative motifs will be discussed at length in this paper.
\end{abstract}

Keywords : Decorative Motifs, Cornice and Plinth, Temple in Java.

\begin{abstract}
ABSTRAK
Motif hias terdapat pada bangunan candi Hindu dan Budha, biasanya digoreskan hampir di seluruh bangunan candinya. Motif hias tersebut berupa relief-relief yang menggambarkan hiasan geometris, alam, tumbuhan, binatang, dan manusia. Relief ada yang merupakan serangkaian cerita bersambung dari panil satu ke panil berikutnya, mengisahkan tentang cerita yang diambil dari epos pewayangan. Selain itu adapula yang menceritakan fabel-fabel yaitu cerita dengan tokoh utama binatang, yang mengandung ajaran moral untuk manusia. Bangunan candi mempunyai 3 bagian pokok yaitu kaki, tubuh, dan atap candi. Di samping itu juga terdapat bagian yang disebut pelipit berfungsi sebagai pemisah antara ke tiga bagian candi tersebut. Untuk memperindah dan memberikan kesan bangunan rampin pada bangunan, maka pada pelipit-pelipit itu diterakan motif hias yang mengelilingi bagian bangunan candi. Motif hias tersebut mempunyai ber macam-macam variasi.
\end{abstract}

Kata kunci: Motif Hias, Pelipit, Candi di Jawa. 


\section{PENDAHULUAN}

Indonesia yang memiliki banyak suku-bangsa tentunya mempunyai beragam hasil karya seni yang terdapat pada bermacam benda produk. Salah satu dari hasil karya seni tersebut berupa motif hias dalam ornamen-ornamen yang terdapat pada tenun, sulaman, anyaman, ukiran, dan arsitektur bangunan. Semuanya itu dapat dibuat pada sehelai kain, bambu, kayu, kulit binatang maupun batu andesit.

Kajian tentang berbagai ornamen ragam hias Indonesia, pertama kali ditulis oleh Van der Hoop pada tahun 1949 dalam bukunya yang berjudul Ragam-ragam Perhiasan Indonesia dalam edisi 3 bahasa, yaitu bahasa Indonesia, Inggris, dan Belanda. Buku tersebut dilengkapi dengan gambargambar yang diambil dari pendokumentasian foto maupun melalui gambar-gambar tangan sebagai ilustrasi. Van der Hoop memulainya dengan latar belakang mengenai tumbuhnya ragam hias di Indonesia, kemudian melalui gambar-gambar berbagai motif hias dari motif geometris, manusia, binatang, tumbuh-tumbuhan, serta benda-benda alam. Secara konseptual tidak dibicarakan tentang pengertian motif hias dan yang terkait, namun buku tersebut setidaknya telah memberikan apresiasi terhadap beragam hasil seni hias Indonesia. Ragam hias atau seni hias adalah suatu hasil karya seni yang dibuat dengan tujuan memperindah suatu bentuk dalam suatu karya seni oleh pembuatnya. Bangsa Indonesia sudah sejak lama mengenal seni hias tersebut, dimulai dari masa Prasejarah yang nampak diterakan pada berbagai benda keperluan upacara seperti nekara, kapak perunggu, dan wadah-wadah mayat (Atmosudiro, dkk. 2008, 155). Selanjutnya pada masa Klasik atau masa Hindu dan Buddha di Indonesia, ragam hias diterakan pada bangunan candi berupa relief-relief yang menghiasi hampir seluruh bangunan candi.

Sebagaimana telah diketahui, bahwa candi secara vertikal dibagi menjadi 3 bagian pokok yaitu kaki, tubuh, dan atap candi. Masing-masing merupakan simbol dari satu tingkatan dunia. Tingkatan itu dalam agama Hindu disebut Bhurloka, Bhuwarloka, dan Swarloka, dalam agama Budha disebut Kamadhatu, Rupadhatu, dan Arupadhatu. Kaki candi (Bhurloka/ Kamadhatu) melambangkan alam semesta, tubuh candi (Bhuwarloka/Rupadhatu) melambangkan dunia antara, dan atap candi (Swarloka/Arupadhatu) melambangkan dunia atas tempat para dewa.

Di samping 3 bagian pokok tersebut, candi mempunyai bagian-bagian penyerta lain, di antaranya:

a. Pelipit, terletak pada ketiga bagian pokok candi, selalu terdapat pelipitpelipit di atasnya. Dengan demikian bagian-bagian candi itu seolah-olah diberi bingkai di bawah dan di atasnya. Pelipit yang terletak di sebelah atas tiap bagian pokok candi, dan letaknya menjorok keluar disebut, bingkai mahkota. sedangkan disebut pelipit atas apabila terletak di bagian atas dari bingkai atas kaki, dan tubuh candi. Begitu sebaliknya, disebut pelipit bawah apabila terletak di bagian bawah dari kaki, tubuh, maupun atap candi (Dumarçay 2007, 92).

b. Bidang hias atau panil dalam suatu bangunan candi atau bangunan lainnya yang sengaja disediakan untuk membuat relief sebagai hiasan. Biasanya seluruh bidang dibagi menjadi beberapa bagian yang membuat bingkai-bingkai yang membatasi tiap-tiap hiasan. Relief yang dipahatkan di tengah bingkai itu dapat berupa hiasan seperti geometris, sulur, daun, bunga dan sebagainya, akan tetapi dapat juga berupa lukisan suatu cerita atau peristiwa tertentu (Ayatrohaedi, dkk. 1981, 15-16).

c. Pilaster adalah tiang segi empat yang menempel atau bersandar pada dinding. Secara teknis pilaster berfungsi sebagai penahan dinding yang disandarinya, dan bukan sebagai penahan bagian bangunan yang ada di atasnya. Pada candicandi umumnya tiang ini dibuat pada sudut-sudut bagian luar candi atau menjadi batas antara bidang hias. 
Jadi fungsinya sebagai hiasan saja (Ayatrohaedi, dkk. 1981, 69).

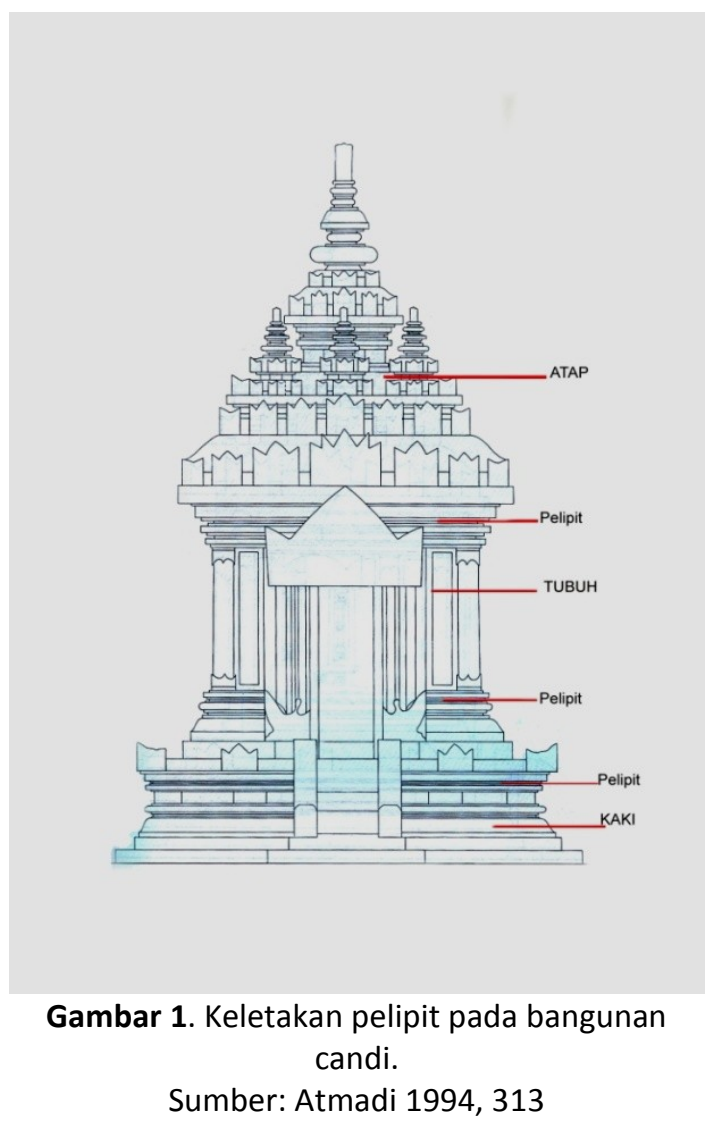

Sementara itu, yang dimaksud dengan karya seni hias adalah sesuatu yang digunakan untuk memperindah atau menghiasi benda lain, yang tidak dapat berdiri sendiri, dan hanya merupakan pelengkap dari benda lain tersebut. Dalam fungsinya dengan bangunan candi, secara konstruktif dapat menambah nilai struktur bangunan dan disebut sebagai hiasan struktural. Namun dapat juga hanya sekedar hiasan tempelan yang tidak mempengaruhi seni bangunan secara struktural. Hiasan struktural tersebut dibagi dua yaitu:

a. Jika motif hias tersebut dihilangkan, akan mengubah bentuk bangunan candi seperti pada relung, tingkatan atap, dan penampil.

b. Motif hias yang keberadaannya sekedar menunjang struktur bangunan candi seperti pada hiasan pilaster, pelipit, dan pelipit (Atmosudiro, dkk. 2008, 156).
Motif hias dalam bangunan candi terdapat hampir di seluruh komponen bangunan candi, pada bagian kaki, tubuh, atap candi, termasuk pada pelipit, panil, dan pilaster. Relief-relief yang dituangkan pada permukaan bidang yang rata pada bangunan candi tersebut mengandung nilai magis religius yang berkaitan dengan latar belakang keagamaan pembangunan candi yang bersangkutan. Ada pula motif-motif yang dibuat hanya sebagai pengisi bidang yang kosong, untuk menambah estetika dan memperindah motif hias yang dituangkan disana.

Sehubungan dengan yang telah diuraikan di atas, maka tujuan penulisan makalah ini adalah, ingin mengetengahkan motif hias pada pelipit bagian bawah dan atas, yang terdapat di kaki, tubuh, dan atap bangunan candi Hindu maupun candi Buddha. Adapun candi-candi yang disurvei berada di wilayah Jawa Tengah dan Daerah Istimewa Yogyakarta.

Metode penelitian yang digunakan adalah metode penalaran induktif, dengan tipe penelitian deskriptifeksploratif. Pengumpulan data dilakukan melalui 2 sumber yaitu, sumber primer dan sumber sekunder. Sumber primer adalah data yang diperoleh dengan mengamati objek secara langsung di lapangan. Sumber sekunder adalah data yang diperoleh secara tidak langsung, melalui laporan hasil survei, tulisan, atau penelitian sebelumnya.

\section{OBJEK-OBJEK YANG DISURVEI}

Tidak semua candi yang berada di wilayah DIY dan Jawa Tengah disurvei untuk menyusun tulisan ini. Hal ini dikarenakan banyaknya candi-candi yang terdapat di dua wilayah tersebut. Jadi dilakukan pembatasan, yaitu pada candi-candi yang yang masih utuh berdiri, dan masih lengkap mempunyai bagian-bagian pokok bangunannya (Istari. 2011). Sebagai ilustrasi, secara singkat akan diuraikan identitas tiap-tiap candi yang telah disurvei, sebagai berikut: 


\section{Candi Prambanan}

Kompleks Candi Prambanan merupakan candi Hindu terbesar yang berada di Pulau Jawa. Terletak di Kabupaten Sleman DIY. Terdiri atas tiga halaman, berdenah bujur sangkar dengan susunan yang konsentris. Terletak di lereng Gunung Merapi dengan koordinat $07^{\circ} 45^{\prime} 08,7$ "LS dan $110^{\circ} 29^{\prime 2} 28,8^{\prime \prime} B T$. Pendirian kompleks candi ini diperkirakan sekitar akhir abad IX Masehi berdasarkan pada prasasti Siwagrha 778 Saka atau 856 Masehi yang dikeluarkan oleh Rakai Pikatan.

\section{Candi Sari}

Terletak di Kabupaten Sleman, DIY. Candi ini didirikan sekitar abad IX Masehi, berlatar belakang agama Budha, dan mempunyai keletakan pada koordinat $07^{\circ} 45^{\prime} 41,5^{\prime \prime}$ LS dan $110^{\circ} 28^{\prime} 27,4^{\prime \prime} B T$. Secara arsitektural candi berdenah persegi panjang dan bertingkat dua. Diperkirakan merupakan sebuah Wihara yaitu tempat bersemedi para pendeta di tingkat atas sedang tingkat bawah sebagai tempat menaruh arca dewa-dewa.

\section{Candi Sambisari}

Terletak di Desa Sambisari, Kelurahan Purwomartani, Kabupaten Sleman dengan koordinat $07^{\circ} 45^{\prime} 45,0^{\prime \prime}$ LS dan $110^{\circ} 26^{\prime} 49,1^{\prime \prime}$ 'BT. Didirikan sekitar pertengahan abad IX Masehi dan berlatar belakang agama Hindu. Arsitektur candinya merupakan suatu kelompok percandian terdiri atas sebuah candi induk dan tiga Candi Perwara, yang dikelilingi oleh pagar tembok dari batu putih, dan mempunyai pintu masuk pada setiap sisinya. Candi induk terbuat dari batu andesit dengan arah hadap ke barat.

\section{Candi Sewu}

Terletak di Dukuh Bener, Desa Bugisan, Kecamatan Prambanan, Kabupaten Sleman, DIY, secara geografis terletak pada koordinat $07^{\circ} 44^{\prime} 38,8^{\prime \prime}$ LS dan $110^{\circ} 29^{\prime} 34,2$ 'BT. lingkungan Taman Wisata Candi Prambanan, merupakan suatu kompleks percandian yang terdiri atas 249 bangunan candi yang berupa satu buah
Candi Induk, delapan Candi Apit, dan 240 buah Candi Perwara.

\section{Candi Plaosan}

Secara administratif kompleks Candi Plaosan terletak di Dukuh Plaosan, Desa Bugisan, Kecamatan Prambanan, Kabupaten Sleman, DIY.Secara geografis terletak pada koordinat $07^{\circ} 44^{\prime} 27.1^{\prime \prime} L S$ dan $110^{\circ} 30^{\prime 16.6 " B T . ~ T e r d i r i ~ a t a s ~ d u a ~}$ kelompok candi yang dinamakan Candi Plaosan Lor dan Candi Plaosan Kidul. Candi ini dibangun sekitar abad IX Masehi oleh Rakai Pikatan dari Dinasti Sanjaya bersama dengan permaisurinya Pramodawardhani dari Dinasti Syailendra, tetapi berlatar belakang keagamaan Budha Mahayana.

\section{Candi Morangan}

Terletak di Dusun Morangan, Desa Sindumartani, Kecamatan Ngemplak, Kabupaten Sleman, DIY, secara geografis terletak pada koordinat $07^{\circ} 41^{\prime} 05^{\prime \prime}$ LS dan $110^{\circ} 28.09$ "BT. Latar belakang keagamaan Hindu, terdiri atas candi induk dan satu buah candi perwara. Keadaan candi sekarang sudah runtuh, dan diperparah lagi sewaktu terjadinya letusan dan banjir lahar Gunung Merapi tahun 2010.

\section{Candi Merak}

Terletak di Desa Gatak Candi, Kecamatan Karangnongko, Kabupaten Klaten, pada koordinat $07^{\circ} 40^{\prime} 12,2$ 'LS dan $110^{\circ} 33^{\prime} 12,5^{\prime \prime} B T$. Kelompok candi ini terdiri atas satu candi induk dengan tiga candi Perwara. Candi Induk berdenah bujur sangkar dan menghadap ke timur, sementara candi Perwara menghadap ke arah barat berhadapan dengan candi induk. Berlatar belakang agama Hindu.

\section{Candi Borobudur}

Terletak di wilayah Kelurahan Borobudur, Kecamatan Borobudur, Kabupaten Magelang, terletak pada koordinat $07^{\circ} 36.29$ LS dan 110 12'14"BT. Dibangun sekitar abad VIII Masehi oleh raja Samarottungga, berlatar belakang keagamaan Budha Mahayana. Tentang kata Borobudur sendiri ada beberapa pendapat para 
serjana, di antaranya Casparis, yang mengatakan bahwa Borobudur sebagai kuil nenek moyang. Hal ini berdasarkan pada sebuah prasasti berangka tahun 842 Masehi yang menyebutkan Kamulan I bhumi Sambhara yang berarti tempat suci atau kuil nenek moyang di Borobudur. Arsitektur candi sebagai berikut: mempunyai 10 tingkatan, tingkat 1 - 6 berdenah bujur sangkar, tingkat 7 10 berdenah lingkaran, dengan arah hadap ke timur. Pada dinding candi terdapat panil-panil relief semuanya berjumlah 1460 dengan ukuran panil rata-rata 2 meter. Mempunyai dinding berukir sebanyak $2500 \mathrm{~m}^{2}$ dan jumlah panil hias seluruhnya 1212 buah (Siagian 2000, 40). Bagian kaki candi atau lantai dasar candi disebut Kamadhatu,bagian tengah candi disebut Rupadhatu, dan tingkat teratas disebut Arupadhatu yang terdiri atas tiga teras berundak berbentuk lingkaran termasuk stupa induk yang melukiskan alam atas sebagai tempat para dewa. Di tingkat ini tampak polos tanpa hiasan relief, tingkatan yang berbentuk lingkaran terdiri atas tiga tingkat dengan 72 buah stupa.

\section{Candi Mendut}

Terletak di Desa Mendut, Kecamatan Mungkid, Kabupaten Magelang, secara geografis mempunyai koordinat $07^{\circ} 36^{\prime} 14,7^{\prime \prime}$ LS dan $110^{\circ} 13^{\prime} 43,6$ "BT. Candi ini berlatar belakang agama Budha, dibangun sekitar abad VIII Masehi.

\section{Candi Ngawen}

Terletak di Desa Ngawen, Kecamatan Muntilan, Kabupaten Magelang, pada koordinat $07^{\circ} 36^{\prime} 14,7^{\prime \prime}$ LS dan $110^{\circ} 16^{\prime} 21,4^{\prime \prime} \mathrm{BT}$. Berlatar belakang agama Budha dan merupakan kompleks percandian yang terdiri atas lima buah candi berjajar dari utara ke selatan dengan jarak tiap-tiap candi kurang lebih 4 meter. Semua bangunan menghadap ke timur. Candi-candi yang masih utuh adalah candi II dan III, sedang candi I, IV, dan V tinggal bagian kaki candinya saja.

\section{Kompleks Candi Gedongsongo \\ Terletak di Kabupaten Semarang}

a. Kelompok Candi Gedongsongo I

Terletak di bagian paling bawah dekat pintu masuk ke kompleks candi. Kelompok candi hanya memiliki satu buah candi yang masih utuh, dengan arah hadap ke barat. Bangunan candi terdiri atas 3 bagian yaitu memiliki kaki, tubuh, dan atap candi, terletak pada korodinat $07^{\circ} 12 ' 29,2^{\prime \prime}$ LS dan $110^{\circ}$ 20'30,2"BT.

\section{b. Kelompok Candi Gedongsongo II}

Kelompok candi II berada pada ketinggian $1270 \mathrm{dpl}$, letaknya sekitar 337 $\mathrm{m}$ ke arah barat-laut kelompok candi I, koordinat $\quad 07^{\circ} \quad 12$ '16,8'LS dan $110^{\circ} 20^{\prime} 26,4$ "BT. Kelompok ini terdiri atas 2 buah candi yaitu Candi Ila yang masih dalam keadaan utuh, mempunyai kaki, tubuh, dan atap candi, arah hadap ke barat. Sedangkan Candi llb tinggal bagian pondasi bangunan dan berada tepat berhadapan dengan Candi Ila.

c. Kelompok Candi Gedongsongo III

Kelompok candi terdiri atas 3 buah bangunan candi yang masih utuh. Berada pada ketinggian $1298 \mathrm{~m}$ dpl, dan koordinat $07^{\circ} 12,14^{\prime} 1{ }^{\prime \prime}$ LS dan $110^{\circ} 20^{\prime} 24,3$ 'BT, jarak dari Kelompok Candi II kurang lebih $118 \mathrm{~m}$. Ke tiga candi tersebut adalah, Candi IIla bangunan paling besar berdenah empat persegi dan pintu masuk menghadap ke barat. Candi IIIb terletak di sebelah utara Candi IIla, berukuran lebih kecil, memiliki denah empat persegi dan pintu masuk menghadap ke barat. Candi IIlc terletak di sebelah barat Candi IIla, mempunyai denah empat persegi panjang dan pintu masuk menghadap ke timur.

\section{d. Kelompok Candi Gedongsongo IV}

Terletak sekitar $220 \mathrm{~m}$ ke arah barat dari Kelompok Candi III, dan berada pada ketinggian $1300 \mathrm{~m}$ dpl, dengan koordinat $07^{\circ} \quad 12^{\prime} 13^{\prime} 3^{\prime \prime}$ LS dan $110^{\circ} 20^{\prime} 17,7^{\prime \prime} \mathrm{BT}$.

Bangunan yang masih berdiri utuh adalah candi induk yang terdapat di bagian selatan. Bentuk candi induk Kelompok IV ini sama dengan candi- 
candi lainnya di Kompleks Gedongsongo yaitu, kaki candi lebih tinggi dengan selasar di atasnya, tubuh candi berdenah bujur-sangkar, dinding tubuh mempunyai relung. Pintu masuk berada di dinding sebelah barat, dengan ambang pintu mempunyai bentuk ragam hias.

\section{e. Kelompok Candi Gedongsongo V}

Berada di atas bukit dengan ketinggian $1310 \mathrm{~m}$ dpl, berjarak sekitar $500 \mathrm{~m}$ dari Kelompok Candi I, dan mempunyai koordinat $07^{\circ} \quad 12^{\prime} 19^{\prime} 6$ 'LS dan $110^{\circ} 20^{\prime} 16,4^{\prime \prime} B T$. Terletak pada 2 halaman yang berteras, halaman 1 lebih tinggi sekitar $1,5 \mathrm{~m}$ dibanding dengan halaman 2. Pada halaman 1 terdapat sebuah candi yang masih utuh dan diapit 2 candi di kiri kanannya yang tinggal reruntuhan saja. Halaman 2 terdapat sebuah candi induk dengan kaki candi setinggi kurang lebih $1,15 \mathrm{~m}$, berdiri di atas batur rendah berdenah persegi panjang.

\section{Candi Asu}

Terletak di Desa Candipos, Kelurahan Sengi, Kecamatan Dukun, Kabupaten Magelang, mempunyai keletakan pada koordinat $07^{\circ} 31^{\prime} 38,7^{\prime \prime}$ LS dan $110^{\circ} 21^{\prime} 05,8^{\prime \prime} B T$ dengan dpl $650 \mathrm{~m}$. Arah hadap ke barat, berdenah bujur sangkar dan hanya satu bangunan candi saja.

\section{Candi Lumbung Sengi}

Terletak di Desa Tlatar, Kelurahan Kroguwanan, Kecamatan Sawangan, Kabupaten Magelang, dengan koordinat $07^{\circ} 31^{\prime} 42,0^{\prime \prime} L S$, 110²0'57,1"BT, dan dpl $750 \mathrm{~m}$, berada di pinggir Sungai Pabelan. Arah hadap candi ke barat dengan denah bujur sangkar.

\section{MOTIF HIAS PADA PELIPIT CANDI}

Candi-candi yang disurvei berjumlah 13 bangunan candi yang masih utuh. Dalam tulisan ini yang akan dibahas adalah motif hias pada pelipit bagian bawah dan atas, yang terdapat pada kaki, tubuh, dan atap bangunan candi.
Motif hias secara sederhana dapat dibedakan menjadi 2 kelompok, yaitu:

\section{Motif hias geometris}

Motif ini menggunakan unsurunsur seperti garis dan bidang yang umumnya bersifat abstrak artinya bentuknya tidak dapat dikenali sebagai bentuk objek alam, tetapi yang dikenal dalam ilmu geometri. Motif ini berkembang dari bentuk titik, lengkung, atau garis-garis yang berulang-ulang, dari yang sederhana sampai dengan pola yang paling rumit. Motif geometris abstrak murni terdapat pada pola anyaman, perulangan garis-garis, lingkaran, segitiga, dan lengkung, yang berkembang menjadi hiasan bentuk meander, pilin, lereng, banji, kawung, jlamprang, dan tumpal (Sunaryo, 2009: 19).

\section{Motif hias organis}

Bentuknya dapat berupa penggambaran manusia, binatang, maupun tumbuh-tumbuhan. Motif ini berkembang pada masa pengaruh Hindu dan Buddha masuk ke Indonesia, dan kemudian menjadi sangat umum karena menjadi bagian utama pada tinggalantinggalan bangunan candi. Motif tumbuhtumbuhan dalam candi digambarkan sebagai pepohonan dan suluran yang merupakan perkembangan dari motif hias pilin. Bentuk sulur adalah sejenis tanaman menjalar dengan pola ikal berulang secara bergantian arah. Motif geometris segitiga menjadi motif pucuk rebung atau tumpal yang nantinya berkembang pula menjadi motif lidah api atau sinar/prabha. Demikian pula motif meander berkembang menjadi motif awan (Sunaryo 2009, 153).

Beberapa motif hias pada pelipit candi di bawah ini, akan menunjukkan bahwa motif hias tersebut dibuat untuk memperindah bangunan candi.

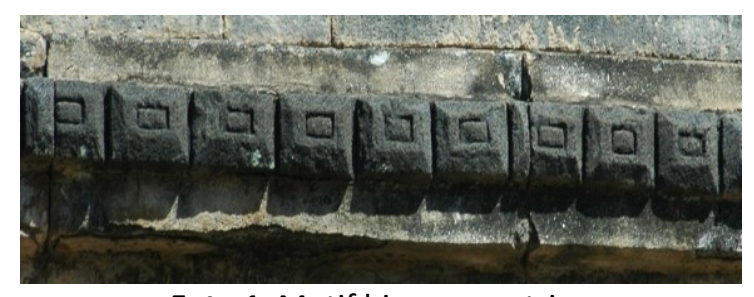

Foto 1. Motif hias geometris 
Motif hias geometris, berupa bujur sangkar dan di tengahnya terdapat bujur sangkar berukuran kecil. Motif ini terdapat pada pelipit Candi Prambanan mengelilingi tubuh bagian bawah candi induk. Pada Candi Sari terdapat mengelilingi pelipit bagian bawah kaki candi. Pada Candi Ngawen terdapat mengelilingi pelipit bagian atas kaki candi. Pada Candi Morangan letak aslinya belum diketahui, karena berupa temuan lepas akibat runtuhnya candi. Juga terdapat mengelilingi pelipit bagian bawah stupa Candi Lumbung Prambanan,

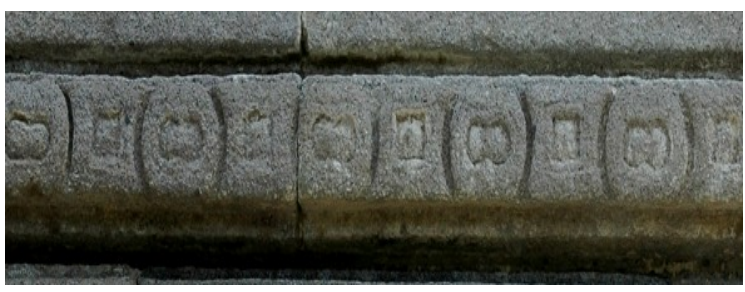

Foto 2. Motif hias geometris

Motif hias geometris, berupa bentuk oval, tanda kurung, dan bujur sangkar. Hanya terdapat di Candi Plaosan, tampak motif ini mengelilingi pelipit bagian atas kaki candi

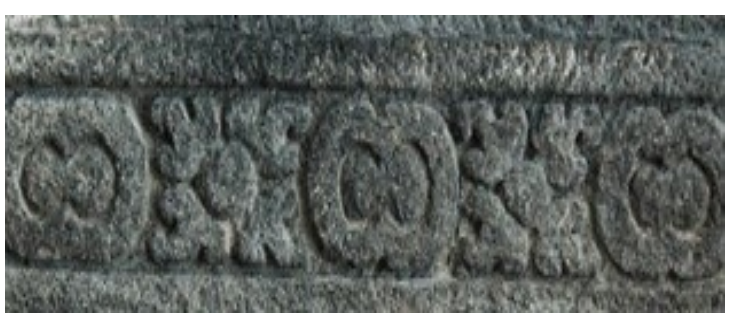

Foto 3. Motif hias kombinasi

Motif hias kombinasi, tumbuhan dan geometris berupa bentuk ceplok bunga dengan bentuk oval. Terletak pada pelipit bagian bawah tubuh candi Brahma, Prambanan. Motif ini juga terdapat di Candi Asu, Candi Pendem, dan Candi Lumbung Sengi, yang letaknya saling berdekatan, dan berasal dari abad yang sama. Terdapat mengelilingi pelipit bagian atas kaki candi

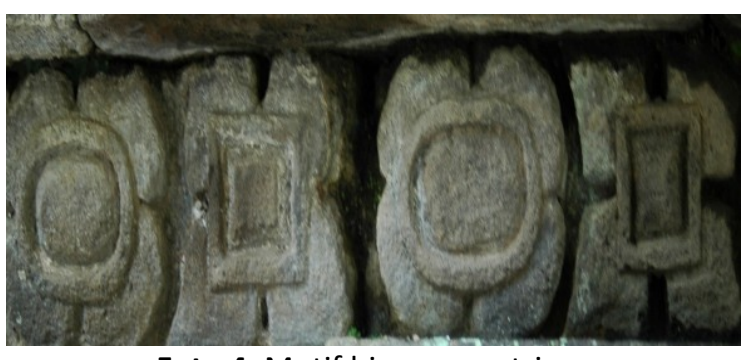

Foto 4. Motif hias geometris

Motif hias geometris semacam ini hanya terdapat di Candi Merak, bentuknya sangat unik, berupa lingkaran oval, dan bujur sangkar, yang diluarnya dibingkai dengan kelopak bunga. Sayangnya sudah banyak yang lepas, hanya tampak sebagian yang masih menempel, dan nampaknya mengelilingi pelipit bagian bawah kaki candi.

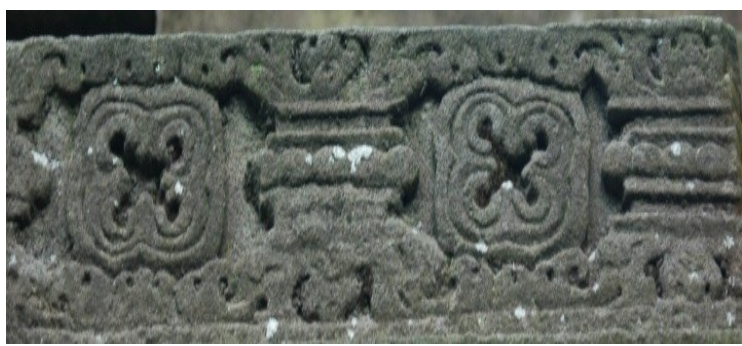

Foto 5. Motif hias kombinasi

Motif hias kombinasi geometris, dan tumbuhan, berupa bujur sangkar, oval, tanda silang, dan suluran. Motif unik ini hanya terdapat di Candi Lumbung Sengi, tampak mengelilingi pelipit bagian bawah kaki candi.

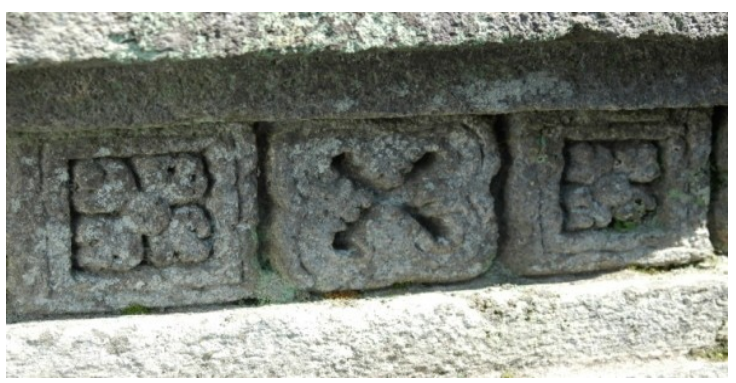

Foto 6. Motif hias kombinasi

Motif hias kombinasi geometris dan tumbuhan, berupa bujur sangkar, tanda silang, dan bunga melati, bagian luarnya dibingkai dengan bujur sangkar. Motif ini hanya terdapat di Candi Morangan, letak aslinya belum diketahui akibat runtuhnya candi, dan runtuhan batu-batu candi ditumpuk di halaman candi. 


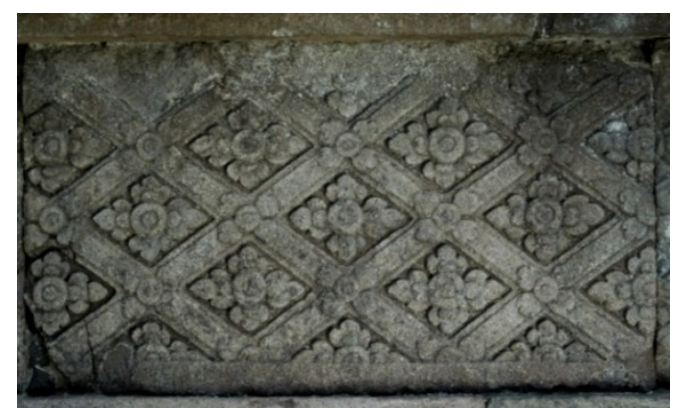

Foto 7. Motif hias kombinasi

Motif hias kombinasi, antara motif geometris belah ketupat, yang di tengahnya terdapat ceplok bunga melati. Motif ini umum didapatkan sebagai hiasan pada candi-candi di Jawa, dipahatkan pada pelipit yang mengelilingi bagian bawah kaki candi, antara lain: terdapat di Candi Mendut, Borobudur, Gedongsongo, Plaosan, dan Merak.

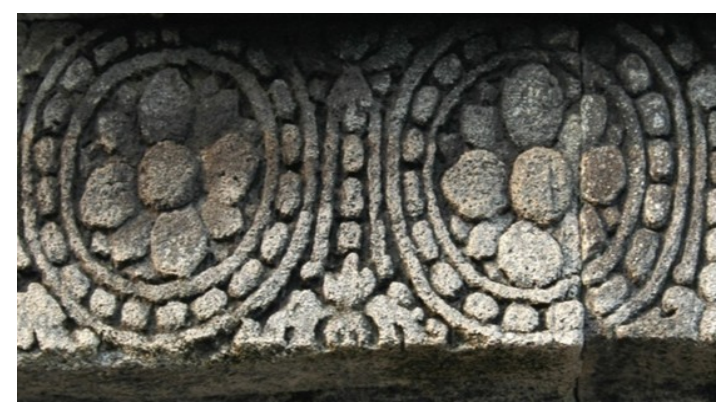

Foto 8. Motif hias kombinasi

Motif hias kombinasi geometris berupa lingkaran, bulat-bulat kecil, dan ditengahnya terdapat tumbuhan berupa bunga matahari, terdapat mengelilingi pelipit bagian atas tubuh Candi Borobudur, dan Candi Sari

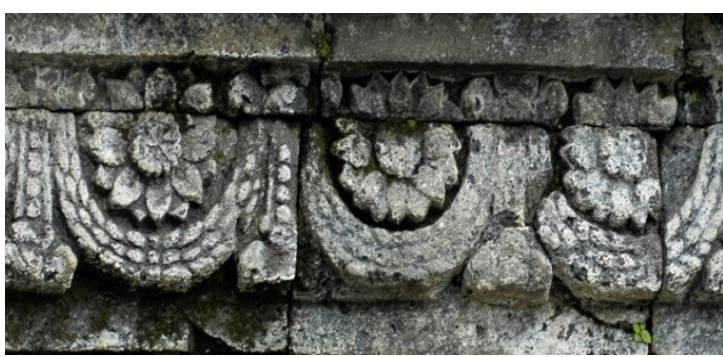

Foto 9. Motif hias kombinasi

Motif hias kombinasi, motif hias semacam ini selalu ada di setiap candicandi Hindu dan Budha, berupa motif hias yang mengelilingi pelipit bagian bingkai kaki, tubuh, atap, pagar langkan, dan stupa disebut motif hias Tirai. Tirai berbentuk lengkung-lengkung dari pita dengan kombinasi di tengah-tengah lengkungan terdapat motif hias lain, seperti bunga, helai daun, dan binatang. Sebenarnya motif ini tidak mengandung arti, hanya sebagai pemanis bidang dan sebagai hiasan pemisah bagian-bagian candi.Sebagian besar candi-candi Jawa Tengah mempunyai motif tersebut, antara lain terdapat di Candi Sambisari, Sewu, Merak, Sari, Lumbung Sengi, Gedongsongo, dan Candi Ngawen. Pada Candi Borobudur terdapat mengelilingi pelipit bagian atas tubuh candinya, dan pada Candi Plaosan terlihat mengelilingi pelipit bagian atas kaki candi.

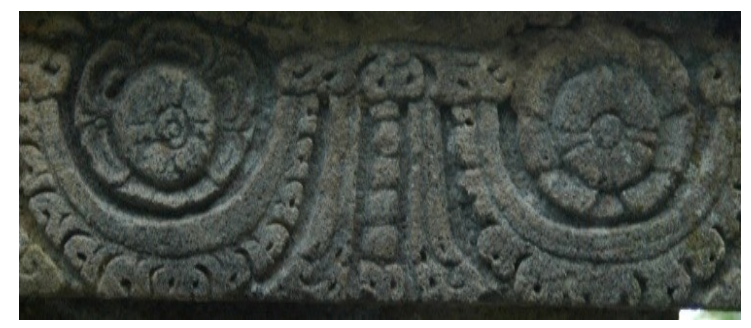

Foto 10. Motif hias kombinasi

Motif hias kombinasi, atau motif Tirai, berupa lengkungan pita dengan ceplok bunga ditengahnya, dan di bawah pita tersebut terdapat sulur-sulur. Motif ini hanya terdapat di Candi Lumbung Sengi, terletak mengelilingi pelipit bagian atas tubuh candi

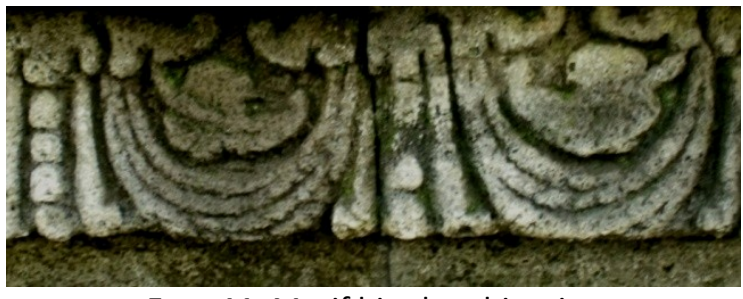

Foto 11. Motif hias kombinasi

Motif hias kombinasi, atau motif tirai. Berupa lengkungan pita dengan helai daun. Terletak mengelilingi pelipit bagian bawah atap, berupa lengkunglengkung pita dengan helai daun di tengahnya, terdapat di Candi Mendut, dan Candi Plaosan. 


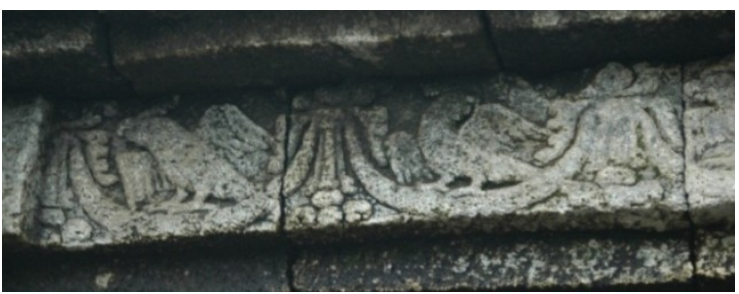

Foto 12. Motif hias kombinasi

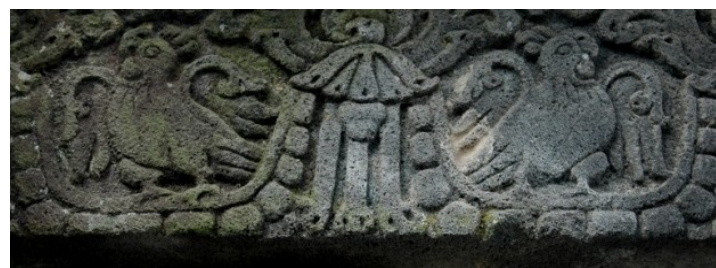

Foto 13. Motif hias kombinasi

Motif hias kombinasi, foto 12 dan foto 13 , sama yaitu motif tirai, berupa kombinasi lengkungan pita, dan di tengahnya terdapat binatang berupa burung nuri dalam posisi ber macammacam. Alasan apa yang mendasari penggambaran burung nuri tersebut, kemungkinan karena dalam kesenian Hindu di Indonesia burung ini dianggap sebagai wahana dewa asmara yaitu Dewa Kama (Hoop, 1949: 196). Burung nuri disamakan dengan burung merpati yang dianggap sebagai burung pengantar surat cinta antara Dewa Kama dengan kekasihnya Dewi Ratih. Jadi penggambaran burung nuri mempunyai makna sebagai lambang cinta kasih dan komunikasi (Sunaryo 2009, 88).

Motif tersebut di atas pada Candi Prambanan terdapat mengelilingi pelipit bagian atas tubuh candi. Pada Candi Borobudur dan Candi Gedongsongo mengelilingi pelipit bagian bawah atap candi. Candi Lumbung Sengi dan Candi Asu, juga mempunyai motif hias tirai yang serupa dengan candi-candi lainnya, tetapi relief yang digambarkan mengelilingi pelipit bagian atas kaki Candi Asu (foto 13) ini tampak lebih raya dan hidup dibanding motif tirai pada candi-candi lainnya.

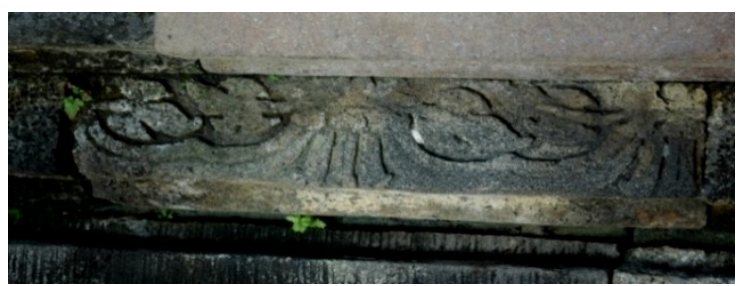

Foto 14. Motif hias tumbuhan
Motif hias tumbuhan, berupa tumbuhan suluran dan helai daun, terdapat mengelilingi pelipit bagian atas kaki Candi Plaosan.

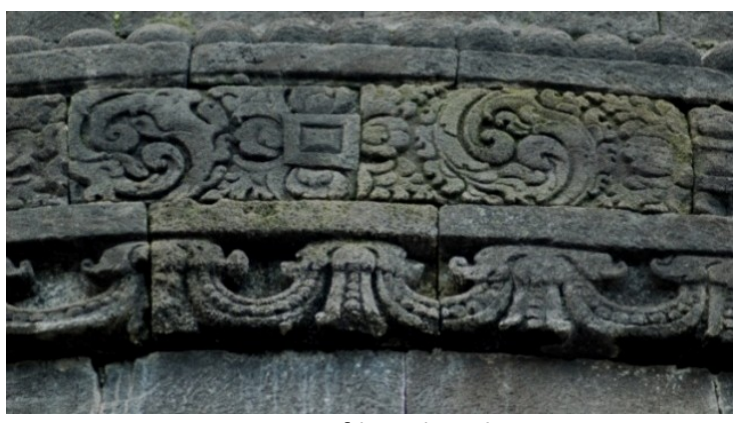

Foto 15. Motif hias kombinasi

Motif hias kombinasi, motif geometris antara lain bujur sangkar, bulatan, dan sulur melengkung, di bagian bawahnya tampak terjuntai motif hiasan tirai berupa lengkungan pita-pita. Motif ini didapat mengelilingi bagian bawah stupa induk Candi Borobudur.

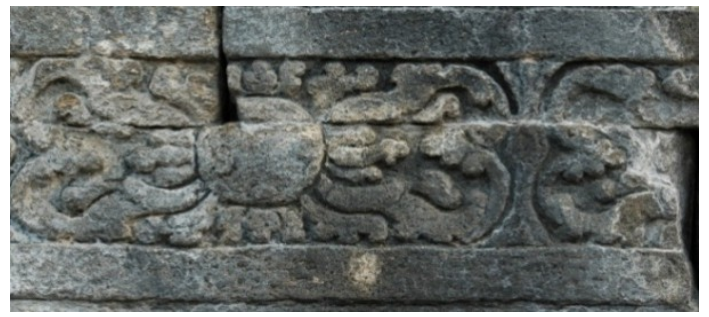

Foto 16. Motif hias tumbuhan

Motif hias tumbuhan, berupa tumbuhan suluran, terdapat mengelilingi bagian bawah stupa induk Candi Borobudur.

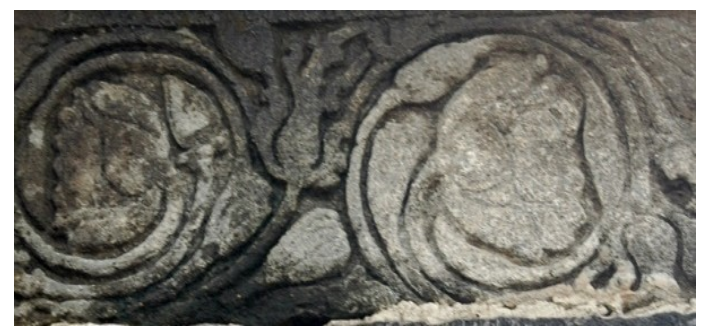

Foto 17. Motif tumbuhan

Motif tumbuhan, berupa kuntum teratai yang keluar dari jambangan seperti ini disebut kumuda, dan dipahatkan mengelilingi pelipit bagian tengah tubuh Candi Sewu. Bunga teratai/padma dianggap melambangkan kemurnian dan kesucian juga mempunyai makna simbolis, 
dimaksudkan menambah nilai sakral bangunan candi tersebut.

Melihat motif-motif hias tersebut di atas, selain adanya relief-relief yang menggambarkan cerita-cerita yang mengandung makna atau simbol religius, rupanya motif hias yang diterakan pada bagian pelipit candi juga tidak kalah pentingnya.

Motif-motif itu dapat dibedakan menjadi 3 kelompok, yaitu:

a. Motif hias geometris: dalam candi biasanya digambarkan dalam bentuk segi empat, bujur sangkar, oval, lingkaran, persegi panjang, belah ketupat, dan sebagainya.

b. Motif hias kombinasi: biasa digambarkan dalam bentuk geometris, dipadu dengan relief bunga, pita atau binatang. Jenis binatang yang sering digambarkan dalam perbingkaian ini adalah burung nuri atau burung merpati.

c. Motif hias tumbuhan, seperti tampak pada foto 14,16 , dan 17, tumbuhan berupa suluran ini tampaknya dibuat hanya sebagai pemanis bingkai tersebut, dan mungkin tergantung dari selera pemahatnya pada waktu itu. Kecuali suluran, motif tumbuhan lain berupa bunga, teratai, melati, matahari, dan helai daun.

\section{PENUTUP}

Definisi dari motif hias adalah suatu pola atau corak hiasan yang terungkap sebagai ekspresi jiwa manusia terhadap keindahan atau pemenuhan kebutuhan lain yang bersifat budaya. Dapat pula dikatakan bahwa motif hias sebagai hasil cipta manusia dalam bentuk motif yang mempunyai nilai seni untuk tujuan tertentu. Oleh karena itu motif hias erat hubungannya dengan kata hati penciptanya atau pembuatnya yang mengacu pada kebutuhan akan pemenuhan kepercayaan berkaitan dengan keindahan,estetika, kemewahan, kekayaan, dan lingkungan hidupnya.

Berdasarkan data-data yang telah dikemukakan, maka dapatlah diambil kesimpulan bahwa, pada umumnya candi-candi mempunyai motif hias pada bangunannya, mulai dari kaki, tubuh bagian luar, pagar langkan, atap candi, maupun pada pelipit yang membatasi bagian bangunan candi.

Saran yang diharapkan adalah agar penelitian tentang motif hias pada bangunan candi, nantinya dapat dibukukan secara lebih lengkap, dan dapat menambah pengetahuan bagi masyarakat luas.

\section{UCAPAN TERIMAKASIH}

Sebagai penutup tulisan ini, penulis mengucapkan terimakasih kepada instansi terkait yaitu, Bidang Kebudayaan pada Dinas Kebudayaan Pariwisata dan Olahraga Kabupaten Sleman, Magelang, Temanggung, dan Semarang. Para staf dan Juru Pelihara dari Balai Pelestarian Cagar Budaya DIY dan Jawa Tengah, yang dengan tangan terbuka melayani tim dalam mencari data-data di candi-candi yang dikunjungi. Tidak lupa pula kepada rekan-rekan anggota tim penelitian Balai Arkeologi Yogyakarta, yang terlibat dalam penelitian ini. 


\section{DAFTAR PUSTAKA}

Ayatrohaedi, dkk. 1981. Kamus Istilah Arkeologi I. Jakarta: Pusat Pembinaan dan Pengembangan Bahasa. Departemen Pendidikan dan Kebudayaan.

Atmadi, Pramono. 1994. Some Architectural Design Principles of Temple in Java. Yogyakarta: Gadjah Mada University Press.

Atmosudiro, Sumijati (editor) dkk. 2008. Jawa Tengah Sebuah Potret Warisan Budaya. Prambanan, Klaten: Balai Pelestarian Peninggalan Purbakala Jawa Tengah dan Jurusan Arkeologi Fakultas Ilmu Budaya Universitas Gadjah Mada.

Dumarçay, Jacques. 2007. Candi Sewu dan Arsitektur Bangunan Agama Buddha di Jawa Tengah. Jakarta: Kepustakaan Populer Gramedia.

Hoop, A.N.J. Th. Van der. 1949. Ragam-ragam Perhiasan Indonesia. Bandoeng: Koninklijk Bataviaasch Genootschap van Kunsten En Wettenschappen.

Istari, Rita T.M. 2011. Ragam Hias Candi-candi di DIY, Jawa Tengah, dan Jawa Timur. Laporan Penelitian Arkeologi. Yogyakarta: Balai Arkeologi Yogyakarta.

Siagian, Renville. 2000. Candi. Sebagai Warisan Seni dan Budaya Indonesia. Yogyakarta: Gadjah Mada University Press.

Sunaryo, Aryo. 2009. Ornamen Nusantara Kajian Khusus Tentang Ornamen Indonesia. Semarang: Effhar Offset. 
